\title{
An Anatomy of Grand Fraud: The Goldenberg Scandal and the IMF/World Bank
}

\author{
Professor Roman Grynberg Mr. Fwasa Singogo* \\ Department of Economics, University of Namibia, Private Bag 13301, Windhoek, Namibia
}

\begin{abstract}
This article considers the largest documented 'gold' fraud on the African continent to this day ${ }^{1}$. The scheme involved, Goldenberg International Limited that would 'export gold and diamonds fictitiously' in exchange for substantial subsidies from the government for 'earning' foreign exchange. This constitutes an important case study of the interaction between the creation of a partially liberalized trade and exchange rate policy environment in Kenya and the deeply embedded culture of corruption in the country that was the cause in effect of the GIL scandal.
\end{abstract}

Keywords: Goldenberg, Gold, Fraud, Africa

DOI: $10.7176 / \mathrm{PPAR} / 10-2-02$

Publication date: February $29^{\text {th }} 2020$

\section{Introduction and Background}

In the early 1990s, the Kenyan government paid what is an estimated US\$ 600-1,500 million ${ }^{2}$ in subsidies to a company and related officials and individuals who claimed to be exporting gold and diamonds that simply did not exist in Kenya ${ }^{3}$. The exact amount that was lost remains in the area of speculation. That so brazen a fraud could occur in a country that produced neither commodity in any significant quantity remains one of the true testimonies of the extent and degree of corruption that existed in Kenya at the time of President Danial Arap Moi. The Goldenberg scandal remains to this day the largest documented 'gold' fraud on the African continent. The substance of what occurred was partially revealed as a result of the Judicial Commission of Inquiry (JCI) ${ }^{4}$ into the Goldenberg scandal which only completed its work in 2005. The scandal cost Kenyan taxpayers hundreds of millions of dollars ${ }^{5}$, but despite a relatively thorough judicial inquiry no one was ever found guilty of any criminal or fraudulent activity 6 . The scheme involved, GIL International that would 'export gold and diamonds fictitiously" ${ }^{7}$ in exchange for substantial subsidies from the government for 'earning' foreign exchange. This constitutes an important case study of the interaction between the creation of a partially liberalized trade and exchange rate policy environment in Kenya and the deeply embedded culture of corruption in the country that was the conditio sine qua non of the GIL scandal.

The scandal centered on two companies; Goldenberg International Limited (hereinafter Goldenberg or GIL) and Exchange Bank Limited (hereinafter Exchange Bank or EBL), both owned and directed by Mr. Kamlesh Mansukhlal Damji Pattni (more commonly referred to as Mr. Kamlesh Pattni or just Mr. Pattni) and James Kanyotu as common shareholders and directors. Mr. Pattni a businessman and his colleague Mr. James Kanyotu, then a Director of Intelligence within the Kenyan Police Force ${ }^{8}$ were the two principal actors in the scandal. The

\footnotetext{
${ }^{1}$ This paper is dedicated to the memory of the late David Sadera Munyakei who, while working as a clerk for the Central Bank of Kenya, provided information to opposition members of the Kenyan parliament in 1993 on the 'exports' of gold by Goldenberg. For his trouble Mr Munyakei was, fired from the Central Bank of Kenya, imprisoned and spent the rest of his life in relative poverty in Mombasa. This is a reminder, if more were ever needed, of the high price that honest men and women pay for telling the truth. He died in 2006.

${ }^{2}$ There are numerous estimates of the amount lost in the Goldenberg scandal. Even the estimates made by the Judicial Commission of Inquiry are imperfect. See Judicial Commission of Inquiry. (2005). Report of the JCI into the GIL Affair. Kenya; Peter Warutere. (2005). 'The GIL conspiracy...' where he asserts that US\$ 600 million to as much as US\$ 1 billion had been siphoned through GIL and that at the peak of the scandal, it was estimated transactions associated with GIL accounted for over 10\% of Kenya's GDP; Xan Rice. (Wed 2 Aug 2006). Top politician escapes $\$ 400 \mathrm{~m}$ Kenya corruption charges. The Guardian. Retrieved from:

https://www.theguardian.com/world/2006/aug/02/kenya; and AfriCOG. (MARCH 2011). ALL THAT GLITTERS? An Appraisal of the Goldenberg Report. AfriCOG. Nairobi, Kenya

${ }^{3}$ Over the three years of the Goldenberg scandal in 1990, 1991 and 1992 Kenya produced $25 \mathrm{~kg}, 20 \mathrm{~kg}$ and $20 \mathrm{~kg}$ respectively. Kenya produced no diamonds. See David Izon. (1994). The Mineral Industry Of Kenya. US Geological Survey https://s3-us-west2.amazonaws.com/prd-wret/assets/palladium/production/mineral-pubs/country/1994/9219094.pdf downloaded May 2019

${ }^{4}$ The JCI began in March 2003, 10 or so years after the scandal was concluded in February 2005. The report was then finally released in October 2005.

${ }^{5}$ See Peter Warutere. (2005). 'The GIL conspiracy...'; The BBC. (March 2006). Q\&A: Kenya's GIL affair. BBC Business. Retrieved from: http://news.bbc.co.uk/2/hi/business/4808618.stm

${ }^{6}$ This is even after several cases were brought against those allegedly involved. See note 767 on page 275 and note 768 on page 276 in the commission of inquiry; Jeevan Vasagar. (2006). Charges in Kenya corruption scandal. The Guardian. Retrieved from: https://www.theguardian.com/world/2006/mar/16/kenya.jeevanvasagar; and The BBC. (March 2006). Q\&A: Kenya's GIL affair. BBC Business. Retrieved from: http://news.bbc.co.uk/2/hi/business/4808618.stm

${ }^{7}$ See Judicial Commission of Inquiry. (2005). Report of the JCI into the GIL Affair. Kenya; Peter Warutere. (2005). 'The GIL conspiracy...' and The BBC. (March 2006). Q\&A: Kenya's GIL affair. BBC Business. Retrieved from: http://news.bbc.co.uk/2/hi/business/4808618.stm

${ }^{8}$ Kanyoto passed away in 2008 leaving an estate of some Ksh. 20 billion. His role as the principle spy of Jomo Kenyata and Arap Moi
} 
GIL scandal which was alleged to have been conceived by the two consisted of a series of fraudulent and irregular business dealings around several Kenyan trade policy programmes, namely; the Export Compensation Act, Pre-shipment Finance and the Retention Scheme which remain common features of trade policy in many African countries until the present day. The second component of the fraud was based on Kenya's distorted exchange rate regime at the time which allowed GIL to make substantial exchange gains as well as illicit returns on Forex Cs as well as on spot and future contracts. The malfeasance of those involved in GIL also extended to random acts of fraud including the purposeful passing of cheques with insufficient funds referred to commonly as 'cheque kiting".

The GIL scandal was perpetrated at a time of severe economic austerity in Kenya with foreign reserves dwindling and the country experiencing a long period of macroeconomic instability. Moreover, in Kenya, there was a high rate of turnover of economic managers in the Ministries of Finance and Planning with no clear economic policies on several key issues and with the IMF and the World Bank setting economic policy at the time. The period of economic austerity also coincided with the creation of a one-party state and the ensuing political oppression. The events added to Kenya's woes as donors gradually reduced support and investment evaporated. Consequently, the government increasingly fell back on local borrowing, with its overseas debt servicing becoming irregular. The economic policies in place at the time leaned towards the protection of certain local industries and regulation of the exportation of foreign exchange out of the country to ensure that limited foreign exchange reserves were not depleted below critical levels.

The obvious question arises as to why one would reflect, after a quarter of a century, on such a gold fraud where no-one was ever found guilty of any crime or misdemeanour? There are several good intellectual reasons for pursuing this matter. First, it shows the relationship between the setting of what would otherwise be sound trade policy that promotes growth must be predicated upon exchange rate systems that do not act to stimulate malfeasance. Second, the Goldenberg scandal is and remains a marker, but only an initial one, in the litany of failures of World Bank/IMF mining and economic policy and its implementation on the African continent in the 1980s through the 1990s. Several other markers, including the origins of what has become known as 'resource nationalism', can be found in the contemporaneous provision by the World Bank of mining taxation policy advice to African countries in the ' 80 s and through the $90 \mathrm{~s}$. Third, given the depth of the investigation by the JCI which constitutes the factual basis for much of what follows, the GIL affair provides a lesson for those who devise economic policy without explicit recognition of state corruption and how that serves to undermine what may, under other circumstances, have been sound policy advice. The last reason for pursuing this matter is that there was at the time very little written by academics on the Goldenberg scandal and this requires rectification because it is such an important lesson in the interaction between policy-making and corruption.

\section{World Bank and IMF Reforms}

The ten or fifteen years following independence Kenya experienced what has come to be termed as the country's "Golden Years" in contrast with the 1980-1990 period that has been commonly referred to as "the lost decade" Having gained independence in the early 1960s, a period of rising commodity prices and global economic expansion and stability, Kenya experienced a period of economic prosperity and had high aspirations given the post-independece commodity prices and its significant foreign reserves. The conditions saw real GDP growth rise by 6.6 percent in the first decade of independence, while savings and investment rates were relatively high ${ }^{3}$. On the other hand, the lost decade was characterized by both external and internal imbalances with soaring oil prices coupled with a global recession at the time which compounded Kenya's internal problems ${ }^{4}$. The deteriorating macroeconomic environment in Kenya eventually led the government to seek assistance from International Financial Institutions (IFIs) that supported the liberalization of economies through the removal of various controls and encouraging investment and trade incentives. In response to the pressure from IFIs and donors, the Kenyan government turned to liberalize its market. This they did by turning to a mixed economy, taking up more of a supervisory role from its previous participatory one. The various measures the country undertook to do so include:

- Promoting the production of industrial and other non-traditional exports with the aim of maintaining a realistic exchange rate,

- Ensuring that export producers had secure and easy access to imported inputs through the Export Compensation Scheme, and

\footnotetext{
suggests strongly the connection of those at the highest levels of Kenyan state in the Goldenberg fraud.

${ }^{1}$ See Judicial Commission of Inquiry; Peter Warutere. (2005). 'The GIL conspiracy...'

${ }^{2}$ See Joseph Kipkemboi Rono. (2002). The impact of the structural adjustment programmes on Kenyan society. Journal of Social Development in Africa. Vol 1, No 1.

${ }^{3}$ Ibid.

${ }^{4}$ These included but were not limited to: fluctuating prices of the country's major exports, drought and famine, increasing debt and the collapse of the east African community.
} 
- Extending to commercial banks pre-shipment credit secured by export bills and discounting such bills at the Central Bank of Kenya.

The government sought to establish export processing zones to attract foreign investment and to stimulate industrial growth and exports. In implementing their export-oriented policies to spur the accumulation of foreign exchange, the government reformed the Export Compensation Scheme by accelerating payments to exporters and expanding eligibility, thereby creating easier access to duty-free inputs. A Pre-shipment Finance Scheme was also introduced to meet the working capital needs of exporters through a Central Bank of Kenya facility for the rediscounting of private financial paper. Furthermore, exporters had Pre-shipment Financial Scheme loans made available to them through Commercial banks "against confirmed and irrevocable letters of credit or confirmed and verified export contracts". The policies mentioned, among others, were at the heart of the GIL scandal that cost Kenyan taxpayers hundreds of millions of dollars as well as part of an Export Development Program which the country had negotiated with the World Bank.

Kenya, like many African countries across the continent, faced a long period of economic stagnation in the 1980s through to the 1990s. This initially triggered a period of policy-making based on "state-led investment" or participation over what were considered key economic sectors. However, the major participatory and state ownership role taken up by governments across the continent failed to spur growth and ultimately proved unsuccessful. Egar to change their fortunes, African states turned to international financial institutions for loans. These loans were provided conditional upon economic reform ${ }^{1}$. Amongst the conditions set for loan assistance was the Kenyan government's implementation of the Export Compensation Scheme and Pre-shipment Finance ${ }^{2}$. The discounting and pre-shipment facility was the basis of assisting exporters with the provision of low-cost working capital.

The implementation of the Export Compensation Scheme and the Pre-shipment Finance scheme, which were at the heart of the GIL scandal, were part of the credit conditions set out by the World Bank for the proposed 1990 IDA credit of SDR 69.5 million (US\$ 100 million) ${ }^{3}$. The implementation of the Export Compensation scheme, the World Bank argued, would accelerate payments to exporters and broaden product coverage 4 . However, the legislation which was on paper based on compensation for taxes paid to the Kenyan government never required the exporter to show that taxes had been paid but only that exports had occurred. Thus the Export Compensation Act ${ }^{5}$ was little more than a thinly veiled and very substantial export subsidy which is precisely what the WTO Secretariat subsequently labelled it ${ }^{6}$. The irony is that the World Bank and the IMF made the implementation of the subsidy, which was the basis of most of the nefarious rents earned in the GIL scandal, a condition of their financial assistance to Kenya.

The third significant scheme used by GIL was the manipulation of the liberalized provisions of the Exchange Control Act. Until the liberalization in 1990 forex had to be held by the CBK and following the liberalization, certain exporting firms were permitted to hold foreign exchange. While it is worth noting that the World Bank did not specify changes in this regard as part of the credit agreement, the Bank propagated the liberalization of markets and one way the Government of Kenya sought to do this was through the Exchange Control Act. This provided the foreign exchange needed to demonstrate to the CBK that export sales did, in fact, occur and were being paid for.

The World Bank's role in advocating these schemes is of significance particularly because the Export Compensation Scheme was one of the main mechanisms used as a conduit for malpractice in the GIL scandal. The World Bank in their recommendation stated that the scheme had been in effect since the 1970 $\mathrm{s}^{7}$ yet it had been suspended in a budget speech by Arthur Magugu, the then Minister of Finance, in 1982/1983 who cited the incidence of fraud as well as the limited impact on export promotion as reasons for the suspension ${ }^{8}$. The World Bank had provided support for policies that were at the very heart of the GIL scandal and to the extent that economic policy throughout many African countries was essentially formulated by the Bank, it must be seen as in part responsible for providing the commercial context in which this fraud occurred.

\footnotetext{
${ }^{1}$ More commonly known as structural adjustment reform.

${ }^{2}$ See export incentives on pages 24 and 25 of the World Bank report and recommendation of the President of the International Development Association to the Executive Directors on a proposed IDA credit of SDR 69.5 million (US\$ 100 million) to the Republic of Kenya in support of an Export Development Project in: World Bank. (1990). Kenya - Export Development Project (English). Washington, DC: World Bank.

${ }^{3}$ Ibid. See page 25

${ }^{4}$ It is worth noting that the World Banks alluded to how, exporters would be able to choose between the EC and exemption schemes, but that safeguards would need to be instituted to prevent the use of both facilities for the same export consignment. This was asignificant distinction that GIL also exploited.

${ }^{5}$ Local Manufactures Act (Export Compensation) 1974, Cap 482. http://www.kenyalaw.org/lex/actview.xql?actid=CAP.\%20482 downloaded July 2019.

6 WTO Secretariat. (2000). Trade Policy Reviews: Kenya Press Release, Secretariat and Government Summaries https://www.wto.org/english/tratop_e/tpr_e/tp124_e.htm\#The\%20Secretariat downloaded July 2019. 'In August 1993, Kenya abolished export subsidies granted under the Export Compensation Scheme.'

${ }^{7}$ See page 16, point 2.10 in World Bank. (1990). Kenya - Export Development Project (English). Washington, DC: World Bank.

${ }^{8}$ See note 102 on page 48 of the commission of inquiry.
} 
The JCI was certainly clear about the central role that the IMF and the World Bank played in creating a policy environment that made the GIL scandal possible. As we shall see below it was the liberalization of the Exchange Control Act that facilitated the movement of forex outside the country that permitted GIL to repatriate foreign exchange in the name of so-called gold export earnings. The Commission report argued ${ }^{1}$

....the various economic schemes which the government later adopted, and which we shall discuss later in this report, were either adopted at the behest of these two institutions (IMF and World Bank) or with their express approval. In addition, the two institutions did not favour protective economic policies and pressed for the repeal or removal from various local legislation of all manner of controls. Top on the list of those legislations was the Price Control Act Cap 504 Laws of Kenya and Exchange Control Act, Cap 113 Laws of Kenya. The economic policies in place at the time leaned towards the protection of certain local industries and regulation of the exportation of foreign exchange out of the country to ensure that limited foreign exchange reserves were not depleted below a certain limit.

\section{Trade Measurs and GIL}

Almost immediately following the implementation of the IMF/World Bank economic policy reforms, whether coincidentally or otherwise, GIL International submitted their application to the Kenyan government for certain privileges that spoke directly to the various economic needs of the country. GIL argued in their submission that their proposal provided an avenue for foreign exchange gains and did so by promising the exportation of nontraditional commodities. However, as a company starting up, GIL argued that it required both incentives and protection to thrive. Goldenberg's application requested ${ }^{2}$ :

- Sole rights to export diamond jewellery and gold out of Kenya for a period of 5 years with the option of an extra 5 years.

- $\quad 35 \%$ Export Compensation on diamond jewellery and gold exports in order to effectively compete with smugglers.

- Its own financial company to reduce security risks given the perceived amounts the company would be transacting in $^{3}$.

GIL International was first registered in July 1990 and amongst its objectives for which the company was incorporated, the following are of particular interest ${ }^{4}$ :

a. To carry on the business of import and export in any or all types of minerals, gold, diamonds, precious and semi-precious stones... in Kenya to all PTA countries, Europe, India and other parts of the world.

b. To prospect, explore, open and work claims or mines and raise dig and quarry for mineral ores, gold, diamonds, precious or semi-precious stones, etc.... in Kenya and other parts of East Africa.

These objectives were of interest, as the JCI investigation into the scandal revealed there was no evidence that GIL had ever engaged in any mining activity of gold and diamonds but rather in smuggling 5 .

Exchange Bank, on the other hand, obtained the necessary banking license before incurring the expense of forming a company - as Kenyan regulations permitted ${ }^{6}$. EBL was a significant conduit for many of Goldenberg's transactions. For a new company of its small size - it is surprising that GIL's request for monopoly status was granted, as other companies of repute were already established in the exportation of both gold and diamond jewellery. Goldenberg's application alluded to Kenya's 'vast' mineral wealth in diamonds and gold - even though at the time, there existed no local supply of diamonds and only a very limited supply of gold, much of which was smuggled out of the country ${ }^{7}$. Ironically, while GIL demanded protection against smugglers, their principle activity was in fact smuggling ${ }^{8}$. GIL further argued for monopoly status by claiming that without it, there would be chaos leading to the undervaluation of the commodities. They further argued that they would be easier to follow up and provide the government with substantial amounts of foreign exchange ${ }^{9}$ if they were

\footnotetext{
${ }^{1}$ Note 64 on Page 31 of the Judicial Commission of Inquiry. (2005). Report of the JCI into the GIL Affair. Kenya. Downloaded from: http://kenyalaw.org/kl/fileadmin/CommissionReports/Report-of-the-Judicial-Commission-of-Inquiry-into-the-Goldenberg-Affair.pdf ${ }^{2}$ See note 78 on page 36 of the Judicial Commission of Inquiry.

${ }^{3}$ It is worth noting that this particular request was not granted. At least not initially. It is also worth noting that while the monopoly status and extra compensation was granted, it was only done so administratively and not through the cabinet or parliament approval. See notes 104 and 105 on pages $49-50$ and note 108 on pages $50-51$.

${ }^{4}$ See note 47 on page 26 of the Judicial Commission of Inquiry.

${ }^{5}$ See note 48 on page 26 of the Judicial Commission of Inquiry; note 131 on pages 59 and 60; and notes 498 and 499 on page 188

${ }^{6}$ See the JCI page 27 point 51 and page 28 point 55 .

${ }^{7}$ See note 80 on page 37 of the Judicial Commission of Inquiry

${ }^{8}$ On two occasions gold which GIL was smuggling into the country was impounded at Wilson Airport after official hours. On both occasions the company brought into the country large amounts of gold respectively, weighing $31 \mathrm{kgs}$ and $32.5 \mathrm{Kgs}$. See JCI note 131 on pages 59 and 60 and notes 498 and 499 on page 188 .

${ }^{9}$ GIL proposed that they expected to handle an estimated 100kgs of Gold to start off with an expectation of a "good supply" of Diamonds.
} 
granted this status as opposed to if there were several companies or individuals involved.

Desperate for a solution to alleviate the country's woes and facilitate an inflow of foreign exchange; a case of ignorance; or the perfect scheme, Goldenberg's application gained approval without proper vetting procedure ${ }^{1}$. At the time of Goldenberg's application, the export compensation fee was a maximum of $20 \%$ of exports. However, $35 \%$ was requested to help enhance mineral trade, particularly the gold trade as propagated by the Commissioner of Mines and Geology then, Mr. Owayo'2. While the rate of export compensation GIL was to be granted was not made public at the time, it was suggested in Parliament that an expansion of the compensation rate would be supplemented with an import duty exemption scheme. GIL was ultimately granted the full $35 \%$ export compensation rate and monopoly rights ${ }^{3}$ without any technical evaluation or approval from the cabinet. All the while other companies' applications/licenses had not been approved or granted, when the law, at least on paper propagated competition ${ }^{4}$.

The section below considers how GIL came to use the various reformed trade measures implemented by the Kenyan government at the behest of the IMF/World Bank. These include the Export Compensation Act, the Preshipment finance scheme and finally the Retention schemes. These trade measures, in one way or another, were intended to stimulate trade and have been used by many countries in Africa to stimulate trade. Per se, there was nothing inherently wrong with these schemes except that they were implemented in the context of Kenya's corrupt political system and this changed everything. They became instruments of fraud because the policy was formulated based on the most common assumption in economics - that the instruments of state policy exist for the public good and not, as is so commonly the case in many countries, for the robbery of the citizenry.

\subsection{The Export Compensation Act}

In the early 1970's faced with a shortage of foreign exchange and a rising trade deficit, the government enacted the Local Manufactures Act (Export Compensation), [Act No.9 of 1974] ${ }^{5}$ which attempted to encourage manufacturing by improving the quality of manufactured goods for export and to address the problems brought on by both external and internal economic shocks - as one of several 'solutions'. The act made it possible for an exporter who had brought in foreign exchange through exports to get a refund of Kenyan taxes paid to facilitate those exports. In its conceptualization, the Export Compensation Scheme anticipated that a firm may wish to import inputs into the country for the manufacture of its product(s). In such a case the importer would have to pay taxes on the imported inputs. In constructing the scheme, the fact that the $10 \%$ reimbursement could be met by the Customs \& Excise Department without significant losses in revenue collection was taken into account because it was assumed the overall foreign exchange earned would mitigate against any such loss. The rate of $10 \%$ of exports was later adjusted to $20 \%$ of exports presumably taking into account the customs department's ability to pay without compromising overall revenue collections. However, there were conditions attached including the eligibility ${ }^{6}$ of a product. Products had to have $30 \%$ domestic value added to them to obtain compensation. Furthermore, there was a shift of emphasis from traditional commodities to non-traditional ones (for instance, shoes - textiles and plastic items). There were numerous pre-conditions for eligibility for the subsidy?

This they estimated would bring in foreign exchange earnings of approximately 1.2 billion Kenyan Shillings or approximately 50 million US dollars - it's equivalent - per year (for the first year with proceeds expected to grow over time).

${ }^{1}$ See the JCI commission of inquiry. Page $37-43$.

${ }^{2}$ A meeting was held on $12^{\text {th }}$ of May, 1988 and came up with three suggestions which were in line with Mr. Owayo' proposal for, among other things, enhanced export compensation as a solution to problems facing gold exports in Kenya. The Ministry of Environment and Natural Resources, the Attorney General's Chambers and Ministry of Commerce were mandated to work towards suitably amending the law to accommodate the proposed changes. However, no action was taken on those recommendations. The law remained unchanged in that regard. See the Judicial Commission of Inquiry, page 40-41.

${ }^{3}$ See points 92,93 and 94 on page $41-42$ of the commission of inquiry. It is worth noting that the Ministry of Finance approved defacto monopoly through administrative and licensing measures despite the fact that the Minister had declined to grant GIL International Limited a monopoly.

${ }^{4}$ See page 50 , notes $106 \& 107$ in the JCI to show the legal position of competition.

${ }^{5}$ While the GIL scandal was devised and executed in the late 1980s through to the early 1990s, the Export Compensation act was first enacted in 1974.

${ }^{6}$ The Local Manufactures (Export Compensation) Act (Cap 482) defined "eligible goods" as goods originating in Kenya. Goods originating in Kenya were defined in the Act as those goods which:

(a) Have been produced wholly in Kenya; or

(b) Have been produced in Kenya and the total value of imported materials, or materials of undetermined origin, which have been used at any stage in the manufacture of the goods does not exceed seventy percent of the ex-factory value of the goods.

The definition does not cover work expended in the production of the goods, only the value of imported goods which was to be taken into account in assessing the $70 \%$ required.

${ }^{7}$ These conditions included:

- $\quad$ Goods which had received a remission, rebate or refund of duty under the Customs and Excise Act, were ineligible.

- $\quad$ Compensation for gold and precious stones could only be paid when the goods were physically examined and certified prior to exportation. Thereafter the foreign currency had to be received by an authorized dealer, usually a bank, within 90 days of the date of payment and evidence of this payment was necessary. 
The compensatory payment was at a rate fixed by Parliament but the Minister had the power to vary it by order $^{1}$. The minister also had the power to include or exclude any goods from the list of eligible items. At the time GIL made its application to the Minister of Finance, the compensatory rate was $20 \%$ of the value of the goods exported. Gold and diamond jewellery were then on the schedule of eligible goods, but not 'mere' gold, whether unwrought or refined. The Export Compensation scheme which was intended to provide incentives to Kenyan exporters was widely abused through corruption. Compensation for exports was paid in the form of cash $^{2}$. Compensation by the Customs Department was paid based on several requirements which in the case of GIL included verification of the exports by the Commissioner of Mines and Geology ${ }^{3}$. This raises the question of how the Commissioner provided verification of these fictitious exports, of a mineral that was mined in only small quantities in Kenya.

As mentioned earlier Arthur Mahugu, the then Minister of Finance, in his budget speech of 1982/1983, suspended the Export Compensation Scheme arguing that it had been used as a vehicle of fraud by some exporters; and that it had a very limited impact on export promotion. However, the suspension came to an end in June 1990, when it was argued that the expansion of the scheme supplemented with an import duty exemption scheme would act as a stimulus to export promotion ${ }^{4}$.

GIL received its final approval in October 1990 and there was a sudden rise, at least statistically, of exports from Kenya. Even though there seemed to be an apparent increase in exports overall, the balance of payments showed a widening deficit ${ }^{5}$. It is important to note that between 1990 and the latter part of 1993 only GIL was granted an export license for gold ${ }^{6}$. However, the Central Bank of Kenya's Board Minutes from 1990 to 1994 at no time indicated that any significant gold and diamond jewellery was exported ${ }^{7}$. Such exports were not even mentioned.

Red flags in regards to Goldenberg's commercial dealings go back as far as its first submission claim for export compensation. Initially, GIL processed its claims through a third party ${ }^{8}$ which, upon the first claim noticed irregularities in regards to exchange control regulations. These included:

1. Overseas payments that were not received through normal interbank transfer but rather through several direct cash deposits in various currencies by the exporter contrary to the Exchange Control which required remittances to be effected by the importer's bank ${ }^{9}$;

2. Funds were remitted by Telegraphic Transfer but there was no indication given in the telex as to the remitter of the money ${ }^{10}$;

3. There was a significant time lag between the deposits and the claims/transactions; and the imbalance between the claims and the deposits made ${ }^{11}$;

4. In some instances, payment for exports were made before export. Most of those payments were

- In the absence of evidence of receipt of foreign currency as set out, a penalty of $3 \%$ a month became payable.

- Foreign currency received in Kenya from tourists or other services was not eligible for purposes of export compensation.

${ }^{1}$ It should be noted that any amount beyond $20 \%$ needed cabinet approval.

${ }^{2}$ See Peter Warutere. (2005). 'The GIL conspiracy...' page 2.

${ }^{3}$ See notes 135 and 136 on pages 61-63 in the Judicial commission of Inquiry. These requirements included:

- $\quad$ CD3 forms were stamped by the necessary authorities. CD3 forms were to be completed for each consignment and the forms were to be obtainable from the bank (commercial bank) which was mandated to receive the export proceeds on behalf of the exporter.

- $\quad$ The values and volumes of the commodities were verified. The commodities being exported were to be assessed by the Commissioner of Mines and Geology who were to confirm the value declared on the CD3 form;

- The CD3 forms would then be returned to the company's/individuals bank which would then give an appropriate preshipment endorsement when it was satisfied that the proceeds of sale had been received through an authorized dealer in Kenya in advance or within the period stipulated under the laws.

Confirmation that all the foreign exchange relating to the exports had been received and sold to the CBK. In the case of Goldenberg, these requirements were based on the expectation that 50 million US dollars were to be guaranteed per annum

${ }^{4}$ It is worth noting that no measures were found by the JCI that the government had instituted to check the fraud Hon. Magugu had pointed out which prompted the government to suspend or reverse the suspension of the scheme. However, hindsight, the loopholes included in real terms: institutional, structural and procedural weaknesses. For one the lack of verification by authorities, when the law mandated it of volume and value of commodities to be exported highlights them clearly provided that the exporter could organize for a hard currency remittance for the receiving bank to sell to the $\mathrm{CBK}$ as confirmation that payments for the exports were received. The Exchange Control Act was effectively repealed by the Finance Act 1993 with effect from $1^{\text {st }}$ of September, 1993.

${ }^{5}$ See notes 132 and 133 on pages 60 to 61 of the Judicial Commission of Inquiry.

${ }^{6}$ See notes 140 on page 64 of the Judicial Commission of Inquiry.

${ }^{7}$ See notes 146 on page 69 of the Judicial Commission of Inquiry.

${ }^{8}$ First American Bank, GIL International's Banker at the time before GIL moved on to use other banks (It is worth noting that First American Bank asked GIL to bank elsewhere after what can only be assumed as irreconciliation of Goldenberg's practices). They were then to submit the returns GIL amassed to the Central Bank of Kenya with the funds sent by Goldenberg's customers abroad. Before the Central Bank endorsed and the Ministry of Finance processed Goldenberg's claims. See: JCI note 154 on page 71; and Peter Warutere. (2005). 'The GIL conspiracy...'

${ }^{9}$ See notes 153 to 157 on pages 71 to 74 of the JCI.

${ }^{10}$ See note 154 on page 71 in the JCI.

${ }^{11}$ See note 158 on page 74 ; note 165 on pages 79 to 80 ; and note 168 on page 81 in the JCI. 
in cash. This was, of course, permitted by regulations, however, such advance payment could only be properly made with the prior approval of the exporter's commercial bank of which none was found ${ }^{1}$.

5. Lastly, although the various remittances were shown as relating to various CD3 forms, the telex messages did not have those details (relevant importer's details and export documents). Rather, the relevant details were supplied by Goldenberg, the exporter. The importer's commercial bank would have been the one to remit the money with full particulars of the export details ${ }^{2}$.

GIL opened various accounts with several banks through which it would receive its purported export proceeds. As soon as GIL had opened an account they would make a cash deposit claiming it was the proceeds of export as the companies to which GIL allegedly exported gold. These companies did not exist and were merely pseudonyms. In effect as no funds in relation to exports were coming in, the funds ought to have been generated by various other means and deposited in the guise of purported exports ${ }^{3}$. The ease with which one could exploit the compensation scheme was best illustrated by a simple example used by Peter Warutere ${ }^{4}$.

In effect, the Goldenberg scheme turned into a multi-million dollar fraud by individuals with both the means and political connections to the ruling elite to do so. All in all, the value of the $20 \%$ export compensation paid to GIL was an estimated US\$ $17,306,516.30^{5}$. Whereas, the $15 \%$ payment totaled about US\$ $3,735,333.77^{6}$. The total paid to GIL under the terms of the Export Compensation Act was an estimated US\$ 21,027,178.717. The export compensation scheme was however not exploited on its own. There were other schemes used to aid in the exploitation of the export compensation scheme.

\subsection{Pre-Export Finance Scheme}

Another important scheme used in the GIL fraud in relation to gold and diamond exports was the pre-export finance scheme. This was part of an Export Development Project that the Kenyan government had negotiated with the World Bank. Pre-shipment finance was assistance by way of loans extended at concessionary rates to an intending exporter to enable the preparation of their goods for export. Not every export was eligible for export compensation but pre-shipment finance covered a wider range of products. The facility was to be available basesd on a bill drawn and payable in Kenyan currency either with or without a letter of credit issued by a commercial bank to finance production expenses for the exporter provided that the exporter had a firm export contract or order. The bill had to be endorsed by the bank (commercial bank ${ }^{8}$. Thereafter, the Central Bank rediscounted the bill at $85 \%$. The credit so obtained was at a low rate of interest of about $16.44 \%$ with repayment to be made on completion of delivery of the goods before maturity or on payment by the importer before maturity ${ }^{9}$.

In ordinary circumstances, and as asserted in the JCI this program would have been a good way of assisting Kenya exporters and so helping the foreign exchange position of the country. There were various beneficiaries of this facility, however, GIL was the largest beneficiary ${ }^{10}$ and drew down payments through various commercial banks that included its sister company - Exchange Bank.

It should be noted that Customs Declaration forms (CD3) were not needed under the pre-shipment finance scheme. An irrevocable letter of credit or a firm contract was all that was needed in the scheme to show an export was intended. Hence the exporter needed to retire the facility within 3 months as it was hoped that within that period, the intended export would have taken place. However, GIL introduced CD3 forms into the scheme. This was understood as an attempt by GIL to circumvent the requirement of an export letter of credit

\footnotetext{
${ }^{1}$ See note 158 on page 74 in the JCI.

${ }^{2}$ It is worth noting that Goldenberg's bankers requested GIL to adhere to good practice; to stop bringing in cash over the counters, and have the relevant documents accompany payment accordingly. See Judicial Commission of Inquiry note 164 on pages 78 and 79.

${ }^{3}$ It is worth noting that in some instances there seemed to be verifiable documentation to support a commodity was being exported. See: note 189 of the JCI o page 89 and note 165 on pages 79 and 80 . However, as the inquiry states, whether exports were indeed made is another story especially in regards to "mere" gold exports (see note 180 on page 86 in the commission of inquiry) which were ineligible (see note 191 on page 90 in the commission of inquiry). Which GIL invoiced. See note 200 on pages 93 and 94.

${ }^{4}$ See page 2 in Warutere, P. (2005). The GIL conspiracy. The game of paper, gold, money, and power. Institute for Security Studies. ISS Paper 117. The example he used showed how an individual would remit money to his wife as she exported a calabash to him. The wife would confirm receipt of export earnings and therefore claim for compensation. The catch was that the wife could declare an inflated price as what the importer was willing to pay. As long as the claim was met, up to $20 \%$ of the claim could be paid as compensation.

${ }^{5}$ Equivalent to Kshs. 1,179,612,151. NB. The exchange rate used henceforth is the 1993 nominal exchange rate to the dollar at 68.16 unless otherwise stated. See Njuguna S. Ndungtj. (MARCH 1999). Monetary and exchange rate policy in Kenya. African Economic Research Consortium - Page 6

${ }^{6}$ Equivalent to Kshs. 254,600,350.00.

${ }^{7}$ Equivalent to Kshs. 1,433,212,501.00. See: note 193 on page 91 in the Judicial Commission of Inquiry.

${ }^{8}$ It should be noted that under the guidelines regulating this facility, banks were required to satisfy themselves that they were financing a preexport activity. In this regard, they were to possess certain documents including confirmed export orders.

${ }^{9}$ It should be noted that the scheme/facility was met with some objection. Specifically to the manner of implementation on the grounds that this left too much discretion on the commercial banks. See note 210 on page 97 of the commission of inquiry.

${ }^{10}$ See note 213 on page 98 of the JCI.
} 
"established and received by the handling local bank from the importer's bank or ... a firm export contract ..."1 By introducing CD3 forms into pre-shipment, GIL succeeded in causing confusion between the proceeds of export and pre-shipment finance and was able to double dip, thus allowing it to fraudulently obtain more money from the Central Bank of Kenya.

The irregularities were brazen and included: CD3 forms bearing the same invoice number but for totally different transactions, complete with a customs entry ${ }^{2}$; various applications were supported by invoices which were also used in applications made on earlier dates/applications ${ }^{3}$; there were instances of no proper sale contracts, no letter of credit from the buyer's bank abroad and no documents verifying the sale ${ }^{4}$; and Bills were outstanding significantly well after their dates of maturity ${ }^{5}$. The pre-export financing scheme was legally ended in March 1993. Nevertheless, payments continued to be made until April 1993. Through the administrative maneuvers, GIL had been assisted to combine claims under the pre-shipment scheme with those under the Export Compensation Scheme ${ }^{6}$.

By the time the Pre-Export finance facility was stopped on 9th March 1993, EBL on behalf of GIL and associated companies had drawn an amount of approximately US\$ 113,213,612.227 and by 2nd April 1993, GIL had outstanding Bills of approximately US\$ 65,226,717.318. Payments continued to be made until 4th April 1993. Approximately US\$ 7,157,710.86 ${ }^{9}$ - was credited to GIL on 10th March, 1993, US\$ 9,656,165.89 ${ }^{10}$ - on 11 th March, 1993, and US\$2,969,056.8811 - on 22nd March, 1993.

Further, from the available evidence, GIL had been irregularly advanced through various commercial banks a total of approximately US\$ $122,654,367.03^{12}$. The second stage of the abuse was that GIL and its associated companies made repeated applications for credit to different banks giving the same documentation in support. From this, it is quite clear that there could have been no genuine financing of exports as of course, there were no exports.

\subsection{The Retention Accounts Scheme}

The Retention Accounts Scheme was part of the liberalization of the Exchange Control within the then ongoing economic reform programme of the Government of Kenya. Like the pre-shipment scheme, the retention accounts scheme was introduced by the exchange Control Scheme and was intended to assist exporters to expedite their exports without having to queue up in the Central Bank for foreign exchange allocations ${ }^{13}$. It is a common policy used in many developing countries with exchange controls and has the same objective to decrease the bureaucracy in accessing forex for the purpose of importing necessary raw materials and intermediate goods. The program was introduced in August 1991, under the Exchange Control Act and authorized banks (who were designated dealers) to facilitate the retention accounts ${ }^{14}$ upon satisfaction "from documentary evidence provided, that proceeds of sales of goods qualify for retention and that receipt has not been unduly delayed."

Authorized banks were allowed to sell foreign currency originating from retention accounts to clients for approved purposes. Such foreign exchange could also be bought and sold by authorized banks at marketdetermined exchange rates in the interbank market as long as the counterparty was an authorized bank and provided the authorized banks made a daily return to the Central Bank on the quoted buy and sell rates in the interbank market at the close of business of any given day. It should be noted that GIL did not maintain any retention account in any of the local commercial banks ${ }^{15}$.

According to a Price Waterhouse report ${ }^{16}$, GIL did hold a retention account with its sister company EBL. However, this scheme like several others was more to do with money laundering as opposed to Goldenberg's

\footnotetext{
${ }^{1}$ See note 205 on page 95 of the JCI.

${ }^{2}$ See note 216 on page 100 of the JCI.

${ }^{3}$ See note 236 on page 105 of the JCI.

${ }^{4}$ See note 220 on page 101 of the JCI.

${ }^{5}$ See note 237 on page 106 of the JCI.

${ }^{6}$ It is worth noting that as GIL had a license to accept foreign currency it became difficult to distinguish proceeds of exports and foreign currency received otherwise. See: note 204 on page 95 of the commission of inquiry.

${ }^{7}$ The equivalent of Kshs. 7,716,639,809/45. See note 239 on page 106 of the JCI.

${ }^{8}$ The equivalent of Kshs. 4,445,853,052/90. See Ibid.

${ }^{9}$ The equivalent of Kshs. 487,869,572. See note 244 on page 107 of the JCI.

${ }^{10}$ The equivalent of Kshs. $658,164,267$. See note 244 on page 107 of the JCI.

${ }^{11}$ The equivalent of Kshs.202, 370,917. See note 244 on page 107 of the JCI.

${ }^{12}$ The equivalent of Kshs. 8,360,121,657. See note 240 on pages 106 and 107 of the JCI.

${ }^{13}$ GIL International Ltd did not maintain any known retention account in any of the local commercial banks. However, as stated in the commission of inquiry, the price Waterhouse report stated that GIL had a retention account with its sister company - Exchange Bank. See page 109 of the commission of inquiry, note 251 .

${ }_{14}$ The funds in retention accounts could be used by the account holder and were restricted to the import of goods and related services, business travel, advertising and marketing expenses, international debt service (verified by Central Bank), and remittance of post-tax dividends of foreign-owned enterprises. Although that list is not exhaustive, it meant that in other cases the CBK's approval was necessary.

${ }^{15}$ See note 251 on page 109 of the commission of inquiry.

${ }^{16}$ Ibid.
} 
purported export dealings. The money in EBL's retention account did not have anything to do with exports ${ }^{1}$. However, through such accounts, GIL was able to retain large sums of money in foreign exchange out of the country. The management of the scheme contributed to the mess in the money market and the economy as a whole as it was used for personal benefit as opposed to the nations benefit as was initially intended, as the country had no control over money in the retention accounts, it lacked the capacity to access foreign aid, and it had nothing to show it had any foreign exchange reserves which lead to its end in March 1993.

GIL did not maintain any known retention account in any of the local commercial banks apart from EBL. The money which was credited into that account did not at all relate to exports.. It is on record that Mr. Pattni admitted that GIL moved money from EBL to Gold Trust Bank Rwanda using a non-existent account ${ }^{2}$. The total amount was approximately US\$ $60,152,582.16^{3}$ worth of foreign exchange. This clearly shows that GIL could transfer money at will using its sister company EBL on the pretext that it was money held in a retention account. Through such accounts, GIL was able to retain large sums of foreign exchange out of the country. Furthermore, foreign exchange was at times used by GIL to buy Forex Cs contrary to the above notice.

\section{The Kenyan Exchange Rate System and GIL}

The trade reform provisions described above were intended to stimulate production and trade in a market context. However, at the time of Goldenberg, Kenya maintained an official pegged exchange rate as well as a parallel market exchange rate system. The existence of this differential shaped policy in the early 1990s as Kenya moved to what was at first a widening differential between the bank and parallel market rates between 1990-93 but led eventually to a policy that resulted in a floating exchange rate system by early 1995 . Not only had the official exchange rate been abolished but further liberalization allowing citizens to hold foreign exchange had gone. Offshore borrowing by residents was allowed in February 1994, but still subject to quantitative limits. Complete liberalization of offshore borrowing was implemented in May 1994 and the remaining restrictions on inward portfolio investment were lifted in January 1995. It was in the period between 1990 and 1993 that GIL made considerable rents from frauds based, in no small part, on the parallel market premium.

Table 1. Percentage Parallel Market Premium on the Official Exchange Rate

\begin{tabular}{|c|c|c|c|c|c|c|}
\hline & $\mathbf{1 9 8 0}$ & $\mathbf{1 9 8 5}$ & $\mathbf{1 9 9 0}$ & $\mathbf{1 9 9 1}$ & $\mathbf{1 9 9 2}$ & $\mathbf{1 9 9 3}$ \\
\hline Kenya & 10.5 & 5.3 & 1.7 & 9.1 & 37.8 & 58.1 \\
\hline
\end{tabular}

Source: Nguyuru H.I. Lipumba. 1997. The liberalization of Foreign Exchange Markets and Economic Growth in Sub-Saharan Africa. UNU World Institute for Development Economics Research (UNU/WIDER).

For GIL to thrive in the way it did, it needed foreign currency that it could then submit under the guise of export revenues. Before GIL had access to foreign currency through the Exchange Control Act or its sister company EBL, the local market was the main source for foreign currency which was bought off the black market and submitted under the pretext of export proceeds. With the Exchange Control Act, FOREX Cs, and Exchange Bank, GIL was able to access the parallel market, as well as the official market and hence, was able to generate significant rents and GIL may not have exploited the scheme to the extent it did. The table above illustrates the growth of the margins between the official exchange rate and the parallel market rate.

As GIL waited on EBL to be registered, it was able, through the Exchange Act to be granted a license by the CBK that enabled it to receive foreign exchange. This was a direct result of the economic liberalization caused by the IMF/World bank adjustment program which was discussed above. The license was enacted to assist foreigners including tourists who brought foreign currency legally into the country for the purposes of their stay often in the form of travellers' cheques. Arrangements were made by which certain hotels, lodges and tourist-oriented businesses were allowed to accept payment of foreign currency in exchange for goods or services. This was on condition that the license holders were under the obligation to offer all foreign currency that came into their possession to an authorized dealer within forty-eight hours. GIL was not an authorized dealer and as such had to offer the foreign exchange to their bankers at the time.

The license enabled GIL to receive foreign currency, which was done by purchasing it from the public ${ }^{4}$. When EBL was finally registered and granted a banking license, it was also licensed as an authorized dealer and the general exchange control regulations applied to it. Foreign currency was purchased from the general public as mentioned earlier, which was later sold to Exchange Bank. In some instances, the money was sent overseas and deposited into EBL Nostro accounts ${ }^{5}$ and later some of that money was transferred back as export proceeds ${ }^{6}$.

\footnotetext{
${ }^{1}$ It is worth noting that the transfer of funds from this account by GIL brought into question whether the account was indeed a retention account. See note 251 on page 109 of the commission of inquiry. Furthermore, under Exchange Control Notice No.38, Retention accounts were to be held in local commercial banks, and not in offshore commercial banks which GIL did as it moved money from EBLto Gold Trust Bank Rwanda.

${ }^{2}$ Ibid.

${ }^{3}$ The equivalent of Kshs. 4.1 billion.

${ }^{4}$ See note 175 on page 84 and noted 178 on page 85 on the JCI report.

${ }^{5}$ A nostro account refers to an account that a bank holds in a foreign currency in another country.

${ }^{6}$ See note 177 on pages $84-85$ of the JCI.
} 
As GIL had obtained considerable amounts in foreign currency, these were deposited as cash in its local bank accounts as proceeds of exports for purposes of claiming export compensation ${ }^{1}$. Thus without the liberalization of the Exchange Act GIL would not have had the foreign exchange needed to be able to claim the amounts it did from the Export Compensation Scheme.

Several other schemes GIL was involved in include but were not limited to: The, Convertible Foreign Exchange Bearer Certificates (FOREX C's) ${ }^{2}$ and exchange rate gains ${ }^{3}$. One of the sources of revenue for GIL was the use of cheque kitting ${ }^{4}$. It is worth noting that not all the schemes exploited were in regard to the purported export of gold but were rather money laundering activities.

\subsection{FOREX C's}

As alluded to earlier, Forex C's were another one of the abused instruments. Forex Cs were introduced in October 1991 and were in effect a tool for legalizing illegally acquired foreign currency. As a result of the introduction of Forex Cs, the Exchange Control Act was amended in November 1991 to remove the requirement for Foreign Currency Declaration. As a consequence, one did not need to declare the source of foreign exchange being brought into the country. Forex Cs gave a right to obtain foreign exchange at the current market rate of exchange. The transfer of the certificate was to be by simple delivery and could be bought from the holders in Kenyan Shillings on a willing-seller, willing-buyer basis at the going market price or any other negotiated price. Forex Cs were issued by the CBK or authorized dealers. Payment for their initial issue was in convertible foreign currency in travellers' cheques issued outside Kenya or remittances from abroad in favor of the issuing office by way of telegraphic transfer, demand draft or any other acceptable mode. The downside of these certificates was that no register of ownership was maintained. Consequently, it was impossible to trace any given certificate. All the more so because the certificate was to be encashed at the office of issue by whoever was in possession of it, at any time after the date of purchase. A premium was payable dependent on the length of time the certificate had been held which was nil for the first year, and a rising rate thereafter.

Forex C's were purchased as a means to obtain foreign currency which was in turn used in the guise as proceeds of exports. In addition, Forex Cs were used by GIL to remit large sums of foreign exchange into offshore bank accounts ${ }^{5}$. Abuses of the system were noted as early as June $1992^{6}$. Export proceeds where compensation had been paid were not eligible, nor were payments through NGOs, foreign governments, institutional bodies nor inward investment by foreign investors. Nevertheless, they were allowed to obtain certificates and so benefit by selling them on. GIL was moving money from Kenya to offshore accounts and transferring some of it back as proceeds of export. What emerged was, that GIL through its sister company EBL opened various bank accounts offshore. EBL opened offshore Nostro accounts ${ }^{7}$. Foreign currency was bought from the general public either in cash or in Forex Cs by GIL "agents/associates", sold to Goldenberg, who through their sister company would transfer the funds to their Nostro accounts. In some instances, GIL "agents/associates" deposited the funds directly into Exchange Banks Nostro accounts ${ }^{8}$.

By February 1993 the shortage of foreign exchange was such that the decision was taken to suspend the Forex Cs in March. Initially, the introduction of Forex C's had proved successful as pressure on the Central Bank for foreign exchange had decreased ${ }^{9}$. The operation of existing Forex Cs was brought to an end in March

\footnotetext{
${ }^{1}$ See note 181 on page 86 of the JCI.

${ }^{2}$ See note 255 on page 111 of the 1 JCI to note 268 on page 115

${ }^{3}$ See note 287 on page 124 of the JCI to note 295 on page 127.

${ }^{4}$ See note 296 on page 128 of the JCI to note 312 on page 131 . The mechanics of this fraud scheme are as follows:

1. Write a check for which there is not sufficient cash in the payer's account.

2. Create a checking account at a different bank.

3. Deposit the fraudulent check in the checking account that was just opened.

4. Withdraw the funds from the new checking account.

The entity harmed by check kiting is the bank that has allowed funds to be withdrawn from the new checking account without first waiting for funds to arrive from the paying bank. Banks combat this problem by not allowing funds to be withdrawn from an account until a certain number of days have passed, by which time the lack of funds in the payer's account will have been discovered. See: https://www.accountingtools.com/articles/check-kiting.html

${ }^{5}$ See note 261 in the JCI on page 113

${ }^{6}$ See note 259 on page 112 of the commission of inquiry.

${ }^{7}$ A nostro account refers to an account that a bank holds in a foreign currency in another bank. Nostros, a term derived from the Latin word for "ours," are frequently used to facilitate foreign exchange and trade transaction.

${ }^{8}$ See note $270-271$ in the JCI on page $166-117$.

${ }^{9}$ It is, however, worth noting that However, as other Central Bank accounts for receipt of foreign exchange were having little income, the bank had to borrow from the Forex Cs Account to meet urgent commitments such as the payment for oil. It was, therefore, proposed that the Central Bank should discreetly enter into the Forex Cs market through the Commercial Banks as brokers but in such a manner as not to shake the market. This would be similar to the Open Market Operations on the domestic scene and would result in a movement of foreign exchange from the Forex $\mathrm{C}$ account into the Bank's regular Account. The Central Bank of Kenya entered the Forex C market. However, due to internal malpractices, the Central Bank was paying a premium above the official exchange rate and thus incurred heavy losses. This adversely affected the strength of the shilling, as much local money was injected into the market. Inflation galloped against what was trying to be avoided. In order to minimize damage, first, the National Bank of Kenya was used to buy up Forex Cs in order to prevent their remaining a
} 
1993 by presidential announcement. Controls were thereafter reintroduced. By this time the rate of inflation was high, at $46 \%{ }^{1}$. The exchange rate collapsed and foreign exchange was very scarce.

After March 1993, EBL had been buying Forex Cs at a premium of between 2/- and 4/- dollars. Between $18^{\text {th }}$ August 1993, and $13^{\text {th }}$ September 1993, the CBK bought Forex Cs of face value US\$ 132,588, 000 from EBL at 15/- a dollar giving the equivalent Kshs. 1,988,820,000/-. At a meeting with commercial banks in November 1993, CBK agreed to pay a premium of 10/- a dollar. On this figure, the total payment to EBL was approximately US $\$ 9,726,232.39^{2}$. Finally, after $19^{\text {th }}$ October 1993 , when the Forex Cs had become worthless, the CBK paid the liquidator of EBL at 10/- to the dollar on $6^{\text {th }}$ and $24^{\text {th }}$ December 1993 , a total of approximately US\$ $2,775,014.67^{3} /-$.

\subsection{Exchange Rate Gains}

GIL had a network of people and banks locally through which it would obtain foreign currency. There were however instances where foreign currency was bought locally either in cash, Forex Cs, Travellers Cheques and sometimes as Foreign Exchange Allocation (FEAL) by GIL associates. GIL would then transfer this money through local commercial banks into their Nostro accounts of correspondent banks overseas. In other instances, the money transferred by GIL's "associates" overseas would eventually find its way back to the company. GIL had a well-coordinated system where once the money was received in any of the offshore accounts, it would be transferred to any of the other accounts, but ultimately it would end up at Citibank, New York ${ }^{4}$ before it was remitted back to the Central Bank of Kenya. The remittance would invariably be accompanied by separate instructions that the money was part of proceeds of exports and one would find certain CD3 form numbers quoted.

GIL was taking advantage of the various schemes of the Export Development Programme to defraud the country not only of the limited foreign exchange but also in terms of the domestic currency. GIL used pre-export finance to purchase foreign currency locally. Such money whenever it was received from CBK was disbursed to Goldenberg's agents/associates, who would use it to purchase foreign currency locally. The foreign currency would then be exported or remitted before it was then returned to Kenya. Export Compensation would then be claimed on the basis of that money which would be disguised as proceeds of exports. There were no exports nor was there any foreign currency earned. GIL through these transactions earned not only export compensation, and ex gratia, also income from variations in the exchange rate and interest from lending the money to other banks through the interbank market.

GIL, through the difference between official and parallel exchange rates and the depreciating currency, made significant exchange gains. Having acquired a license to accept/trade in foreign currency, GIL was given the authority to accept foreign currency in either cash, traveler's cheques or Forex C's. The introduction of Forex Cs opened the way for GIL to take foreign exchange offshore on either of two pretexts:

- That it was for various investors 5 .

- That there were business people who needed payment overseas.

Through this procedure, GIL transferred large amounts of foreign exchange to its off-shore accounts. The Exchange Control on these retention accounts allowed the Central Bank of Kenya to sell foreign exchange at the official exchange rate for a limited range of uses only. GIL bought foreign exchange from the Central Bank ${ }^{6}$ at the official exchange rate and thereafter exported it. GIL later transmitted the funds back into the country. GIL through the Exchange Bank, its sister company, resold some of the funds back to the Central Bank but at a much higher exchange rate - thus making considerable gains. During the period 1992/93, the CBK was buying currency from the inter-bank markets at a premium above the official exchange rate. As a result of those transactions, the bank incurred a loss of approximately US\$111,502,347.42 $2^{7}$ during that year ${ }^{8}$. GIL through EBL used the gains to purchase other instruments and in turn, made more money 9 .

drain on the reserves. This they did and the removal was at a reasonable cost. See note 264 in the JCI on pages 113 and 114 .

${ }^{1}$ See Njuguna S. Ndungtj. (MARCH 1999). Monetary and exchange rate policy in Kenya. African Economic Research Consortium - Page 6.

${ }^{2}$ The equivalent of Kshs. 662,940,000. It is worth noting that these figures include the premiums paid.

${ }^{3}$ The equivalent of KShs. 189,145,000. It is worth noting that these figures include the premiums paid.

${ }^{4}$ Which is believed to have been the "main collecting bank" for remitting funds back to Kenya. See note 279 of the JCI on page 120.

${ }^{5}$ Forex Cs as stated earlier were intended to attract investors into the country so that they would bring their money and invest it either in treasury bills, which were attracting high-interest rates or in local enterprises. Whatever incomes which were earned could be remitted out of the country. The Forex $\mathrm{C}$ was a convenient instrument for taking the money out of the country as on surrender the investor was allowed to take away his money along with the interest/dividend earned. GIL through EBLexported large sums of foreign exchange on the pretext that it was for various investors when it was not so. See JCI note 288 , on pages $124-125$

${ }^{6}$ However, these purchases are believed to have been fraudulent. See JCI note 289, on page 125.

${ }^{7}$ Equivalent to Kshs.7.6 billion. It is worth noting in this instance the 1993 exchange rate is used for simplicity as calculations including premiums not known and two period exchange rates would not be feasible.

${ }^{8}$ It is worth emphasizing that the amounts lost were through interbank market transfers and may not be attributed to GIL alone.

${ }^{9}$ See JCI note 292, on page 127. 


\section{The Role of the Presidency and the Political Elite}

The role of Kenyan president Daniel Arap Moi and the Kenyan political elite in regards to the GIL affair cannot be understated. It received inadequate attention in the JCI even though there had been a change of government. It may be argued that the JCI did interrogate the role the state played in the affair but, it can and was argued that those tasked with the inquiry were themselves not impartial and certainly not separate from the individuals and organs of state they were investigating. Given the limitations of the JCI, it is, however, worth noting that extensive work was done and considerable light was shed into the dealings of Goldenberg and high levels of the state.

As the inquiry went on, it was noted that several "key" witnesses pointed to the role of the then Head of State (Daniel Arap Moi) and his Vice President who was also the Minister of Finance (Prof. Saitoti) at the time of the GIL affair. These two senior figures were pointed out by those giving evidence as being involved in the affair, either covertly or overtly. What is certain is that GIL would not have existed and the entire fraud not have occurred without the involvement of Moi and Saitoti. Explicit or otherwise. Kenya was and remains a state with rules and regulations however, all seemed to fail around Goldenberg.

In regards to Moi, the statements from the witnesses varied and his "involvement" is not clear cut. When witnesses were pressed as to why even though a directive was given once, it was not followed up? As trivial as the question may seem it ate away the credibility of witnesses. An instance is that of Mr. Magari, the Permanent Secretary of Finance who recalled receiving a phone call from Moi after he had denied one of Pattni's claims of approximately US\$ $38,145.54^{1}$ for compensation of alleged exports ${ }^{2}$. He recalled how Moi asked for the payment to be made, to which his response was he couldn't as the law did not permit $i^{3}$. However, he was then asked by the president how the payment could be made the following day ${ }^{4}$. To this, he allegedly told the president that it could, subject to ${ }^{5}$ :

- There being a draft amendment Bill at the bed of that file [GIL file at Treasury] and on which there was a covering letter for him to sign and forward the Bill to the Attorney General for publication.

- The second condition being that he preferred that the Minister (Prof. Saitoti) signs the forwarding letter to the Attorney General as he did not believe in the monopoly being given to Goldenberg. To which he alleges to have been told Prof. Saitoti would be there at exactly 7.00 a.m. to sign the document

- The third condition was that Parliament would have to pass the bill.

Magari testified that Moi was in agreement and that Prof. Saitoti arrived the following day and took the GIL file, the Draft Bill and the cover letter which had been amended to make Saitoti the signatory of the letter. Thereafter, the witness effected a payment of approximately US\$ 52,472.71 ${ }^{6}$. Magari then testified that as there were moves to regularize the payment to GIL, of the additional $15 \%$ ex gratia, the payment was administratively redesignated as "Customs Refund" even though it was not a Customs refund. He then admitted that he was party to the redesignation and continued making the payments disguising them as customs refund even when he was fully aware that the conditions agreed upon between him and the President had not been fulfilled.

Saitoti's involvement in GIL was more public and far more pernicious than that of Arap Moi. Almost all of Goldenberg's operations were during his tenure as minister. Saitoti as the Minister of Finance at the time granted GIL exclusive rights to engage in gold and jewellery export trade and allowed it the additional $15 \%$ export compensation even when it was against the Local Manufactures [Export Compensation Act]. Saitoti was repeatedly advised against the ex gratia payments but was not deterred. It is worth noting that all through the inquiry neither Moi nor Saitoti appeared before the JCI to testify ${ }^{7}$. What is clear is that without their involvement the GIL affair would not have had gained approval for its fraudulent program nor had payments made to it. The beneficiaries of the GIL scandal included many in the political elite of Kenya at the time including Moi's family as well as some of the most senior officials of the Kenyan government, including the in Bank of Kenya, the Ministry of Mines and the Ministry of Finance (Please see annex for a list of those who either benefited directly or were supposed to be prosecuted following the completion of the JCI).

\section{The Demise of Goldenberg}

For nearly two years, GIL went unchecked until June 1992, when Jilo Fulana, MP, raised in parliament several questions by Private Notice to the Minister for Finance ${ }^{8}$. These being:

\footnotetext{
${ }^{1}$ The equivalent of Kshs. 2.6 million. It is worth noting that this amount was for the $15 \%$ ex gratia and not export compensation.

${ }^{2}$ See note 555 on page 207 of the JCI.

${ }^{3}$ Ibid.

${ }^{4}$ See note 556 and 557 on pages 207 and 208 of the JCI.

${ }^{5}$ Ibid.

${ }^{6}$ The equivalent of Kshs. 3,576,540. See note 556 on page 208 of the JCI.

${ }^{7}$ See notes 13-16 on pages 10-11 of the JCI; AfriCOG. (March 2011). ALL THAT GLITTERS? An Appraisal of the Goldenberg Report. AfriCOG. Nairobi, Kenya - page 19; and Warutere, P. (2005). Op. cit. - page 11 where he asserts Moi refused to testify.

${ }^{8}$ While questions in regards to Goldenberg came as early June 1992, when Nagin Pattni who testified to supplying Hon. Falana relevant information and material that enabled Hon. Falana to raise the questions in Parliament. See note 523 on page 197 of the JCI. It was only until
} 
- Why had GIL been granted a monopoly in the gold and diamond jewellery exports for about two years?

- How much money in foreign exchange the government had earned through the company for the period 1990 and 1991 ?

- Whether gold and diamond jewellery itemized on $\mathrm{CD} 3$ forms had actually left the country?

In response to his first question, he was told that the monopoly was given to GIL in 1991 simply because it had shown that during the two months it had operated in 1990 it had done better than 78 other companies in similar business put together - which was far from the truth ${ }^{1}$. Circumstantial evidence of its undertakings backed by official stamps eventually became public knowledge. The suspicions that GIL was not a genuine exporter but merely claiming export compensation for "paper transactions" eventually became public knowledge through one publication by the Daily Nation in mid-19932.

Pressure from within and from donors rose for the prosecution of the perpetrators of the GIL affair. There were demands for an explanation of how the affair transpired and subsequently, demands for good governance. However, this is alleged to have come with a hurried effort to keep the alleged perpetrators from being prosecuted $^{3}$. The pressure lead to the filling of several cases. However, none were ever concluded from 1994 when they were instituted, to 2003 when the Commission of Inquiry was formed thereby leading to the termination of the cases ${ }^{4}$. To date, none of those who were scheduled for prosecution were brought to book ${ }^{5}$.

The much anticipated JCI report into the GIL scandal at the time sought to get to the root of the scandal and offer some conclusions. Years after the various inquiries, Kenya failed to make any progress in regards to prosecuting those involved in the GIL scandal. The scandal in effect adding the inquiry to its list of ventures in which its association has literally led to the siphoning off of even more of Kenyan taxpayers money ${ }^{6}$. Indeed, as the JCI asserted in its report;

"One can think of no other matter that has engaged the time of all organs of the Government as much as the 'GIL scandal'. Nothing in the public perception has come to epitomize corruption as the GIL scandal."

\section{Conclusion}

When all was said and done, GIL had claimed to have exported gold and diamond jewellery worth approximately US\$ 375 million, including US\$ 250 million worth of so-called exports to World Duty-Free which was was purchased by GIL $^{7}$ and US $\$ 30$ million worth to non-existing foreign firms ${ }^{8}$. The grand total that, according to the JCI, recipients of Goldenberg proceeds received was estimated to be Kshs $158,283,576,592.16^{9}$ or US\$ 2.3 billion. The amounts paid to GIL and the volume of exports reported to the JCI are not readily reconcilable. The difference between the estimates provided in the introduction and this estimate is that the former is based on actual payments to GIL by the Government of Kenya and the latter estimates includes benefits derived by GIL from money laundering activities.

It is worth mentioning that the list in the article's annex illustrates individuals and companies with connections to the state and that the list containing the recipients of Goldenberg proceeds is very much longer. Due to the differences between the official and black-market rate of the Kenyan Shilling trade based on differences between the two were profitable, both as an importer and exporter, the margins were there for the taking as Kenyan Shillings were then exchanged for foreign currency and could be resold at the parallel rate of exchange.

The level of money laundering and abuse of the various trade and foreign exchange facilities was truly mindboggling. Given even the most cursory knowledge of Kenya's mineral resources at the time that such an enormous fraud could continue for two years based on the export of minerals that did not exist in the country is

Mr. David Sadera Munyakei who, while working as a clerk for the Central Bank of Kenya, provided information to opposition memebers of the Kenyan parliament in 1993 on the dealings by Goldenberg that concret evidence surfaced publiclly. Mr. Munyakei noticed irregularities in the processing of export compensation monies to a little-known company; Goldenberg International. After receiving warnings to keep quiet about the matter, he smuggled the incriminating documents to opposition MPs who tabled them in Parliament. David lost his job and was jailed for some time. See AfriCOG. (March 2011). Op. cit. - page iii; and note 801 on page 288 of the JCI.

${ }^{1}$ See note 523 in the JCI on page 197.

${ }^{2}$ Specifically on the $23^{\text {rd }}$ April 1993 . See note 801 on page 288 of the JCI.

${ }^{3}$ See: Peter Warutere. (2005). 'The GIL conspiracy...'

${ }^{4}$ See note 768 in the JCI on page 276.

5 See Xan Rice. (2 Aug 2006). Top politician escapes £400m Kenya corruption charges. The Guardian. Retrieved from: https://www.theguardian.com/world/2006/aug/02/kenya; Daily Nation. (November 24 2012). How Goldenberg scandal was hatched and executed. Daily Nation. Retrieved from: https://www.nation.co.ke/news/How-Goldenberg-scandal-was-hatched-and-executed-/10561628532-8k2yos/index.html; Daily Nation. (APRIL 19 2013). Pattni cleared in Goldenberg scam. Daily Nation. Retrieved from: https://www.nation.co.ke/news/politics/Pattni-cleared-in-Goldenberg-scam/1064-1753240-wyojmn/index.html. See also: AfriCOG. (MARCH 2011). Op. cit. - pages 22-27.

${ }^{6}$ The JCI is estimated to have cost US \$20 million. See Peter Warutere. (2005). 'The GIL conspiracy...'

${ }^{7}$ See Warutere, P. (2005). Op. cit. - Page 10.

${ }^{8}$ Ibid.

${ }^{9}$ See appendix “N" on page 372 of the JCI and http://www.jaluo.com/goldenberg/Recipientsofgoldenberg.pdf 
proof of the collapse of government under Arap Moi. Yet with no proof of gold or diamond exports whatsoever GIL could benefit from the Export Compensation Act for a product which was not part of Kenya's known production and exports. As if this were not enough, the company went on to exploit several regulations that at least on paper were sound economic policy. In 1990 the World Bank and IMF insisted on the implementation of the export subsidies in the Export Compensation Act as a precondition for Kenya's financial assistance after the Kenyan government had in fact suspended the Act in 1982 because of corrupt abuse. Yet the bulk of the nefarious rents earned by GIL stemmed not simply from the abuse of the Export Compensation Act but the many other transitional arrangements that were in place at the time. The reimplementation in 1990 of the Export Compensation Act at the behest of the World Bank was nevertheless the foundation for the GIL fraud. The history of corrupt abuse of that Act did not deter its reimplementation nor lead to its discontinuation after evaluation was undertaken a year or so after the GIL proposal had been approved ${ }^{1}$.

This paper argues that the policies implemented at the behest of the IFIs were in part responsible for the GIL fraud. The long transition from a regulated inward-looking economy with its parallel exchange rate to one with a free-floating exchange rate by 1995 also provided systematic incentives for rent-seeking behavior. The IFIs were unquestionably in control of Kenya's economic policy at the time of the Goldenberg scandal. Furthermore, the existence of high-level corruption within the Kenyan state, a conditio sin qua non for the wholesale fraud emanating from Goldenberg, could hardly have been a revelation to anyone in the IFI's at the time. Yet the IFIs implemented and oversaw policies that created the basis for the economic rents which Goldenberg reaped. There simply was no 'Kenyan economic policy' at the time to which one can apportion blame and it is difficult to find anyone else responsible for the looting of the Kenyan state than the Kenyan political elite and those in Washington who wrote Kenya's policy.

\section{References}

AccountingTools. (2018), “Check kiting". AccountingTools. [Online] Available: https://www.accountingtools.com/articles/check-kiting.html (February 06, 2018).

AfriCOG. (2011), “ALL THAT GLITTERS? An Appraisal of the Goldenberg Report”. AfriCOG. Nairobi, Kenya. Available: https://africog.org/wp-content/uploads/2011/03/Goldenberg_Report2029_03_20111.pdf

Daily Nation. (2004), “A close look Pattni's web of companies”. The Daily Nation. [Online] Available: https://www.nation.co.ke/news/1056-266896-lrkyviz/index.html (Feb 29, 2004).

Daily Nation. (2012), "How Goldenberg scandal was hatched and executed". Daily Nation. [Online] Available:https://www.nation.co.ke/news/How-Goldenberg-scandal-was-hatched-and-executed-/10561628532-8k2yos/index.html (November 24 2012).

Daily Nation. (2013), "Pattni cleared in Goldenberg scam". Daily Nation. [Online] Available: https://www.nation.co.ke/news/politics/Pattni-cleared-in-Goldenberg-scam/1064-1753240wyojmn/index.html (APRIL 19 2013).

David Izon. (1994), “The Mineral Industry Of Kenya”. US Geological Survey. [Online] Available: https://s3-uswest-2.amazonaws.com/prd-wret/assets/palladium/production/mineral-pubs/country/1994/9219094.pdf

David Okwemba. (2006), "The rise and fall of powerbrokers". Daily Nation. [Online] Available: https://www.nation.co.ke/news/1056-162710-mbqivnz/index.html (December 27 2006).

Jeevan Vasagar. (2006), "Charges in Kenya corruption scandal". The Guardian. [Online] Available: https://www.theguardian.com/world/2006/mar/16/kenya.jeevanvasagar

Joseph Kipkemboi Rono. (2002), "The impact of the structural adjustment programmes on Kenyan society". Journal of Social Development in Africa. Vol 1, No 1.

Judicial Commission of Inquiry. (2005), "Report of the JCI into the GIL Affair". Kenya. Available: $\mathrm{http}$ //kenyalaw.org/kl/fileadmin/CommissionReports/Report-of-the-Judicial-Commission-of-Inquiry-intothe-Goldenberg-Affair.pdf

Kiarie Njoroge. (2016), "Is Evans Ondieki the kingmaker in Nairobi politics?" Business Daily. [Online] Available:https://www.businessdailyafrica.com/Is-Evans-Ondieki-the-kingmaker-in-Nairobi-politics1539444-3062950-kt9mt3/index.html (February 4, 2016).

Laws of Kenya. Local Manufactures Act (Export Compensation) 1974, Cap 482. Available: http://www.kenyalaw.org/lex/actview.xql?actid=CAP.\%20482

Nguyuru H.I. Lipumba. (1997), “The liberalization of Foreign Exchange Markets and Economic Growth in SubSaharan Africa". UNU World Institute for Development Economics Research (UNU/WIDER).

Njuguna S. Ndungtj. (1999), "Monetary and exchange rate policy in Kenya". African Economic Research Consortium

Sunday Nation. (2006), "Recipients of Goldenberg money". Sunday Nation. [Online] Available: http://www.jaluo.com/goldenberg/Recipientsofgoldenberg.pdf (February 12, 2006).

\footnotetext{
${ }^{1}$ See See commission of inquiry; note 105 , on page 49 ; note 112 , on page 53 and note 114 , on page 53.
} 
Warutere, P. (2005), “The GIL conspiracy. The game of paper, gold, money, and power”. Institute for Security Studies. ISS Paper 117 Available: https://issafrica.s3.amazonaws.com/site/uploads/Paper117.pdf

The BBC. (2006), “Q\&A: Kenya's GIL affair”. BBC Business. [Online] Available: http://news.bbc.co.uk/2/hi/business/4808618.stm (March 2006).

World Bank. (1990), "Kenya - Export Development Project (English)". Washington, DC: World Bank. Available:http://documents.worldbank.org/curated/en/896851468273620443/Kenya-Export-DevelopmentProject

WTO Secretariat. (2000), "Trade Policy Reviews: Kenya Press Release, Secretariat and Government Summaries". Available: https://www.wto.org/english/tratop e/tpr e/tp124 e.htm\#The\%20Secretariat

Xan Rice. (2006), “Top politician escapes $£ 400$ m Kenya corruption charges”. The Guardian. [Online] Available: https://www.theguardian.com/world/2006/aug/02/kenya (2 Aug 2006).

\section{Annex}

A majority of the recipients of GIL's money were either Mr. Pattni's family or close associates ${ }^{1}$. However, listed below are individuals and institutions with ties to the state along with those who at the end of the JCI investigation in 2003 were prohibited from leaving Kenya ${ }^{2}$.

\section{LIST OF BENEFICIARIES OF GOLDENBERG AND THOSE INITIALLY INDICTED}

\begin{tabular}{|c|c|}
\hline Companies and Names of Individuals & Amount \\
\hline $\begin{array}{l}\text { Goldenberg International Ltd (Mr. Pattni \& Mr. Kanyotu - coconspirators*). Mr Kanyotu } \\
\text { was Mr. Pattni's business partner and a former Special Branch chief. }\end{array}$ & $35,322,354,287.90$ \\
\hline $\begin{array}{l}\text { Uhuru Highway Development (At an ordinary general meeting of the company held on } 12^{\text {th }} \\
\text { February, } 1985 \text { the fully paid up capital was set out to Mohammad Aslam, H.E. Daniel } \\
\text { Arap Moi, C. Kirubi, W. Wurungi, and G. Lindi. Of which the president's share was } 40 \% \text {. } \\
\text { However, when the JCI followed up on the company, it was found that the company file } \\
\text { was not produced before them nor was it available in the Companies' Registry) }\end{array}$ & $40,566,295.20$ \\
\hline $\begin{array}{l}\text { Multiphasic Export Co. Ltd. (The Commission singled out former President Moi, his aide } \\
\text { Joshua Kulei and former PS Joseph Magari } \\
\text { as well as a company called Multiphasic Company Ltd for 'further investigations' to } \\
\text { determine their roles, 'if any', in the whole scam, and whether they were, 'in any way, } \\
\text { involved in any wrongdoing'. This was to be done 'at the discretion of the Attorney- } \\
\text { General.' })\end{array}$ & $15,000,000.00$ \\
\hline Permanent Secretary - Treasury & $1,129,000.00$ \\
\hline Hon. Said Hemed Said (A politician) & $4,000,000.00$ \\
\hline Gideon Moi (A politician. Son of Kenya's second president, Daniel Arap Moi)* & $8,000,000.00$ \\
\hline Philip K. Moi (A retired army officer. Son of Kenya's second president, Daniel Arap Moi)* & $1,421,384.00$ \\
\hline Mr. Mutula Kilonzo, Mr. Moi's Lawyer (Became Justice Minister after Goldenberg affair)* & - \\
\hline Mutula Kilonzo \& Co. Adocates (Pansal/PAB transaction) & $2,175,000$ \\
\hline Kilonzo \& Co. Shapley \& Barret Advocates (PAB purchase by Pansal) & $783,000.000 .00$ \\
\hline Mutula Kilonzo Advocates & $7,000,000.00$ \\
\hline Mr. Joshua Kulei, Mr. Moi’s former Personal Assistant* & - \\
\hline Ismail \& Ismail Advocates( J. C. Kulie \& K. Pattni) & $26,000,000.00$ \\
\hline Eric Kotut, former Central Bank of Kenya Governor* & - \\
\hline Eliphas Riungu, former Deputy Governor of the Central Bank of Kenya* & - \\
\hline Job Kilach, former employee of Central Bank of Kenya* & - \\
\hline Michael Wanjihia, former employee of Central Bank of Kenya* & - \\
\hline Tom Werunga, former employee of Central Bank of Kenya* & - \\
\hline Philip Murgor, former Director of Public Prosecutions* & - \\
\hline Charles Mbindyo, former Treasury Permanent Secretary* & - \\
\hline Wilfred Karuga Koinange, former Treasury Permanent Secretary* & - \\
\hline Joseph Magari, former Treasury Permanent Secretary* & - \\
\hline Prof. George Saitoti (Then Minister of Finance and Vice President)* & - \\
\hline K M Pattni* & $55,702,041.80$ \\
\hline
\end{tabular}

\footnotetext{
1 See The Daily Nation. (Feb 29, 2004). A close look Pattni's web of companies. The Daily Nation. Retrieved from: https://www.nation.co.ke/news/1056-266896-lrkyviz/index.html

${ }^{2}$ For the complete list see either the JCI appendix "N" on page 360-372 or http://www.jaluo.com/goldenberg/Recipientsofgoldenberg.pdf

${ }^{3}$ See notes 434 and 435 on page 171 of the JCI

${ }^{4}$ See AfriCOG. (MARCH 2011). ALL THAT GLITTERS? An Appraisal of the Goldenberg Report. AfriCOG. Nairobi, Kenya
} 


\begin{tabular}{|l|l|}
\hline Companies and Names of Individuals & Amount \\
\hline Collins Owayo, former Commissioner of Mines and Geology* & - \\
\hline Arthur Ndegwa, Senior Mining Engineer in the Commissioner of Mines, Nairobi Office* & $2,000,000.00$ \\
\hline Francis Cheruiyot, former Commissioner of Customs and Excise* & - \\
\hline Elijah arap Bii, former General Manager of Kenya Commercial Bank* & - \\
\hline Hon. Moses Wetangula (A politician) & $150,000.00$ \\
\hline Abraham Kiptanui (was a comptroller of State House) & $3,000,000.00$ \\
\hline Ondieki Evans (lawyer with connections to Moi family) ${ }^{2}$ & $18,050,000.00$ \\
\hline
\end{tabular}

Authors' compilation from: Judicial Commission of Inquiry. (2005). Report of the JCI into the GIL Affair.

Kenya. Downloaded from: http://kenyalaw.org/kl/fileadmin/CommissionReports/Report-of-the-JudicialCommission-of-Inquiry-into-the-Goldenberg-Affair.pdf; AfriCOG. (March 2011). ALL THAT GLITTERS? An Appraisal of the Goldenberg Report. AfriCOG. Nairobi, Kenya. Downloaded from: https://africog.org/wpcontent/uploads/2011/03/Goldenberg_Report2029_03_20111.pdf; and Recipients of Goldenberg money. Downloaded from: http://www.jaluo.com/goldenberg/Recipientsofgoldenberg.pdf ;'*' implies was prohibited from leaving the country and ordered to surrender any weapons they possessed.

\footnotetext{
${ }^{1}$ See https://www.nation.co.ke/news/1056-162710-mbqivnz/index.html A comptroller of State House is the chief accounting officer and secretary to the president. However, the role of comptroller depends on how the President/Boss wants to run his house.

${ }^{2}$ See https://www.businessdailyafrica.com/Is-Evans-Ondieki-the-kingmaker-in-Nairobi-politics-/539444-3062950-kt9mt3/index.html
} 